\title{
Analysis of Cash Flow Components, Gross Profit, Earnings per Share on Stock Returns Manufacturing Company Listed in the Indonesian Stock Exchange from 2016 Until 2018
}

\author{
Nur Azizah*, Muhamad Muwidha, Marlina Magdalena \\ State Polytechnic of Malang \\ Malang, Indonesia \\ *azizah.azim04@gmail.com, muhammadmuwidha03@gmail.com, magdanana14@gmail.com
}

\begin{abstract}
The research objective was to determine the effect of cash flow components consisting of operating cash flow, investment cash flow, financing cash flow, gross profit, and earnings per share on stock returns. The population is the annual report of manufacturing companies listed on the Indonesia Stock Exchange for the period 2016-2018. Samples were taken of 32 company annual reports using purposive sampling method. Data collection using the documentation method. Data were analyzed using Multiple Linear Regression. The results of the operating cash flow analysis do not have a significant effect on stock returns. Investment cash flow has no significant effect on stock returns. Financial cash flow has no significant effect on stock returns and the results of gross profit analysis do not have a significant effect on stock returns. Meanwhile, earnings per share analysis has a significant effect on stock returns. Based on the results of the analysis, it can be concluded that the components of cash flow and gross profit are not reference variables for investors in making investment decisions and earnings per share are the main targets in making decisions. Therefore, companies must pay attention to earnings per share to attract investors.
\end{abstract}

Keywords-cash flow components, gross profit, earning per share and stock return multiple linear regression

\section{INTRODUCTION}

In its role as an economic function, the capital market makes it easy to transfer funds from parties who have excess funds (investors) to parties who need funds (issuers). Capital is said to have a financial function because it gives the owner of the funds the possibility and opportunity to obtain returns according to the characteristics of the chosen investment.

Investors generally expect returns that are more than what they have done, so investors are required to be more careful when they want to invest. The main requirement for investors to want to invest through the capital market is a sense of security for their investment and the rate of return that will be obtained from it.
This investment consists of dividends and capital gains (losses). Financial reports are one source of information that investors can use in making investment decisions. Therefore, financial statement analysis is considered important to understand the information contained in these financial statements. The steps used in the analysis of financial performance through this financial statement are different and different for each industry, including cash flow statement analysis, income statement using gross profit figures, and ratio analysis in the form of Earning per share.

Profit is one of the company performance parameters that is the main concern of investors and creditors. In this study, we use the gross profit figure to see the effect on stock returns from investing in company stocks. This is based on the results of Nurdiana [1] which proves that the gross profit figure has better earnings quality than the other two profit figures presented in the income statement, is more operative, and is more able to provide a better picture. relationship. between earnings and returns on shares.

With this similar research, it discusses the components of cash flow, gross profit and earnings per share [2], the researcher states that operating cash flow has a significant effect on stock prices, while investment cash flow and financing cash flow have no significant effect. on stock prices, whereas according to Rizak and Ana [3] in his research that partially accounting profit has a significant effect while operating cash flow, investment cash flow, financing cash flow, and company size have no significant effect on company stock returns and simultaneously all variables in the study effect on stock returns. Based on the descriptions and research results that still have different results and different proxies, this study aims to analyze the effect of the components of cash flow, gross profit, and earnings per share on stock returns in manufacturing companies. 


\section{RESEARCH METHODS}

Stock return is the result obtained from investment. According to Hartono [4], "stock returns are the results obtained from stock investments. The return can be in the form of realized returns that have occurred or expected returns that have not occurred but are expected to occur in the future. " Return that is realized is the return that has occurred and is calculated using historical data. The return realization is important because it is used as a benchmark for company performance.

According to Hartono [4],

$$
\text { Return = capital gain }(\text { loss })+\text { yield } \text {. }
$$

Capital gain or capital loss is the difference from the current investment price relative to the price of a certain period, it can be found by:

$$
\text { Capital gains }(\text { loss })=\frac{p t-p t-1}{p t-1}
$$

Information:

$\mathrm{Pt}=$ Share price at period $\mathrm{t}$

$\mathrm{Pt}-1=$ Share price in period $\mathrm{t}-1$

The definition of cash flow according to Rahman Pura [5] defines a cash flow statement as follows: "The cash flow statement is a report that describes cash inflows (cash receipts) and cash outflows (cash disbursements) in a certain period".

According to Dwi Martani [6], in general, the flow statement consists of three parts, which are the company's cash transactions, namely as follows:

- Operating Cash Flow (Operating Activities) Represents transactions of operational activities which are reported in profit or loss. Because these operating transactions are short-term, the main accounts in current assets and current liabilities are related to the flow of operating activities.

- Cash Flow Investing (Investing Activities) Represents transactions related to changes in non-current assets, including investments and intangible assets.

- Funding Cash Flow (financing activities) Represents transactions related to long-term

- liabilities and company equity as the company's main source of transactions.

Operating cash flow according to Harahap [7] operating cash flow is an activity included in this group which is the main revenue-producing activity of the company and other activities that are not investment activities and derivative activities. Investment cash flow according to IAI [8] cash flow statement from investing activities is the acquisition and disposal of long-term assets and other investments that do not include cash equivalents. Separate disclosure of activities is important because cash flows are expenditures that have been incurred for resources that generate future income and cash flows. For example: advances and loans made to other parties (other than advances and credits given by financial institutions). The definition of activity cash flow according to IAI [8] is cash flow that comes from activities that result in changes in the amount and contribution of the entity's borrowed capital.

Hery [9] defines transaction activities which include transactions obtained from cash or returned to fund owners (investors) and creditors. So what is included in controlling activities includes transactions relating to long-term debt or equity (capital) of the company.

According to Hanafi et al [10], gross profit is the difference between sales and the company's cost of goods sold. In order for the company's operations to be profitable, the company's operations must be planned carefully and carried out according to the plans that have been made. The implementation of the plan must always be monitored and if irregularities occur then action must be taken immediately before the situation gets worse. Gross profit analysis is an ongoing process and must be carried out effectively.

To compile the gross profit according to Jusup [11] can use the following calculations:

$$
\text { Gross profit }=\text { Net sales }- \text { Cost of goods sold }
$$

According to Sujarweni [12], defines Earning Per Share (EPS) as follows:

"The ratio of earnings per share or also known as the ratio of book value, is a ratio to measure management's judgment in achieving benefits for shareholders."

According to Hanafi et al [10] The formula for calculating earnings per share of a company is as follows:

EPS $=\frac{\text { Net income }}{\text { number of shares }}$

The population in this study are all manufacturing companies in Indonesia that have listed their shares on the Indonesia Stock Exchange (IDX) for the period 2016 and 2018. While the sample in this study comes from a population selected through the purposive sampling method. The data source used is the company's annual report which will be analyzed using the documentation method. The dependent variable in this study is stock returns and the independent variables are operating flow, investment cash flow, cash flow, gross profit and income per share. The conceptual framework proposed is as follows Figure 1: 


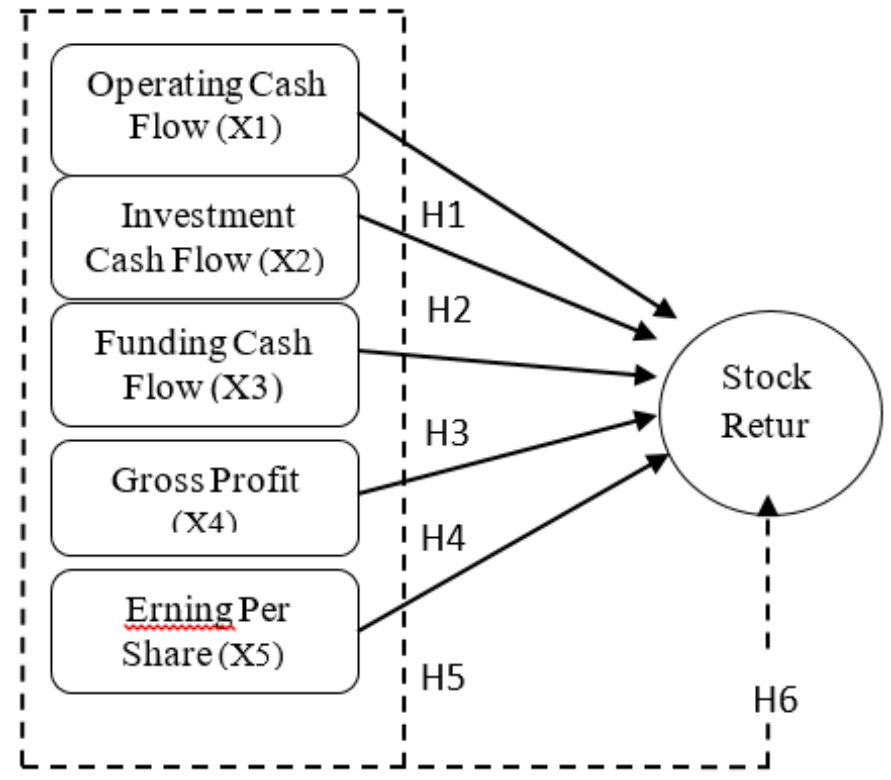

Fig. 1. Concept framework.

\section{Information:}

Individual Influence (Partial)

\section{Effect together (Silmutan)}

The analytical tool used is analysis. Multiple linear regression analysis is the relationship between two or more independent variables and the dependent variable.

Regression Formulas:

$$
\mathrm{Y}=\mathrm{a}+\mathrm{b} 1 \mathrm{X}_{1}+\mathrm{b} 2 \mathrm{X}_{2}+\mathrm{b} 3 \mathrm{X}_{3}+\mathrm{b} 4 \mathrm{X}_{4}+\mathrm{b} 5 \mathrm{X}_{5}+\mathrm{b} 6 \mathrm{X}_{6}+\mathrm{e}
$$

Information:

$$
\begin{aligned}
& \mathrm{Y}=\text { Return Shares } \\
& \mathrm{A}=\text { Constant } \\
& \mathrm{b} 1-\mathrm{b} 5=\text { Regression Coefficient } \\
& \mathrm{X} 1=\text { Cash Flow from Operating Activities, } \\
& \mathrm{X} 2=\text { Cash Flow from Investing Activities } \\
& \mathrm{X} 3=\text { Cash Flow from Financing Activities } \\
& \mathrm{X} 4=\text { Gross Profit } \\
& \mathrm{X} 5=\text { Earnings Per Share (EPS) } \\
& \mathrm{E}=\text { Confounding Variable }
\end{aligned}
$$

And using the partial significance test (t-test) and simultaneous significance test (F-test).

- H1: The Effect of Operating Cash Flow Information on Stock Returns
- H2: The Influence of Investment Cash Flow Information on Stock Returns

- H3: The Effect of Funding Cash Flow Information on Stock Returns

- H4: The Effect of Gross Profit on Stock Returns

- H5: Effect of Erning Per Share on Stock Return

- H6: Effect of Operating Cash Flow, Investment Cash Flow, Funding Cash Flow, Gross Profit, and Earning Per Share on Simultaneous Stock Returns.

\section{RESULTS AND DISCUSSION}

TABLE I. NORMALITY TEST

\begin{tabular}{|l|c|l|}
\hline \multicolumn{1}{|c|}{ Test } & Sig. & \multicolumn{1}{c|}{ Conclusion } \\
\hline $\begin{array}{l}\text { Kolmogorov } \\
\text { Smirnov }\end{array}$ & 0,639 & Normal data \\
\hline
\end{tabular}

Based on the table 1 above, it is known that the Kolmogorov Smirnov significance value is 0.746 and the significance value is 0.639 . Based on these results, it shows that the Kolmogorov Smirnov significance value is greater than the significance value $(0.639>0.05)$ meaning that the data in this study are normally distributed.

TABLE II. Multicol LineARITy TeSt Results

\begin{tabular}{|l|l|l|c|}
\hline No & \multicolumn{1}{|c|}{ Variable } & Tolerance & VIF \\
\hline 1 & Cash flow from operating activities & 0,175 & 7.070 \\
\hline 2 & Cash flows for investing activities & 0.482 & 2.077 \\
\hline 3 & Activity cash flow & 0.375 & 3.332 \\
\hline 4 & Gross profit & 0.287 & 4.805 \\
\hline 5 & EPS & 0.976 & 1.024 \\
\hline
\end{tabular}

Based on the table 2 above, it is known that the VIF value of the cash flow variable for operating activities is 7,070 and the tolerance value is 0.175 . In the cash flow variable in investing activities, the VIF value is 2.077 and the tolerance is 0.482 . The variable VIF value of cash flow activities is 3,332 and the tolerance value is 0.375 . The variable VIF value of gross profit is 4.805 and the tolerance value is 0.287 . The variable VIF EPS value is 1.024 and the tolerance value is 0.976. These results indicate that the VIF value is less than 10 and the tolerance value is more than 0.1 , so it can be stated that the data does not occur multicollinearity.

TABLE III. AUTOCORRELATION TEST

\begin{tabular}{|l|c|c|}
\hline Autocorrelation & Score & Criteria \\
\hline Durbin Watson & 1,980 & $\mathrm{du} \leq \mathrm{d} \leq(4-\mathrm{du})$ \\
\hline
\end{tabular}

Based on the table 3 above, it is known that the Durbin watson value is 1.980, while the Du value is 1.803 and the 4DU value is 2.197 . Thus, it can be stated that $1.803<1.980$ $<2.197$, so it can be stated that the data has no autocorrelation. 


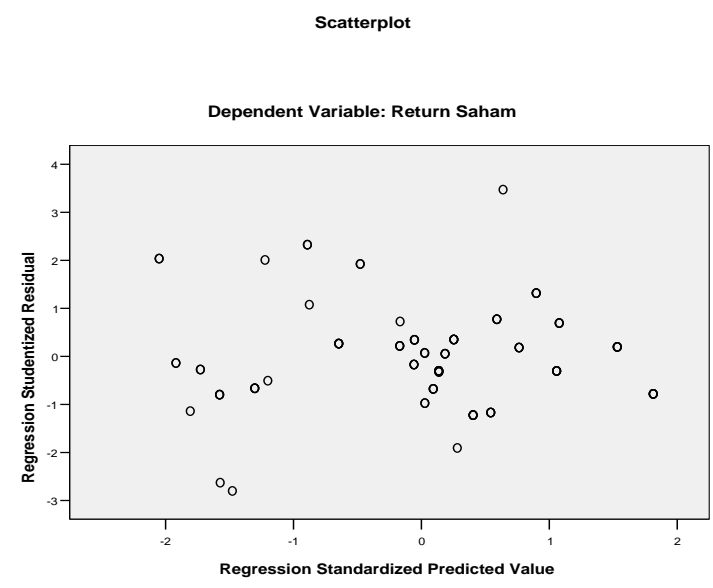

Fig. 2. Heteroscedacity test.

Based on the figure 2 above, it is known that the point spreads above and below 0 on the $\mathrm{Y}$ axis. This indicates that heteroscedasticity does not occur and if there is a certain pattern, there is a symptom of heteroscedasticity.

TABLE IV. MULTIPLE LINEAR REGRESSION ANALYSIS

\begin{tabular}{|l|l|l|}
\hline No & \multicolumn{1}{|c|}{ Variable } & \multicolumn{1}{|c|}{ B } \\
\hline 1 & Constant flow from operating & 273,628 \\
\hline 2 & $\begin{array}{l}\text { Cash flow } \\
\text { activities }\end{array}$ & \\
\hline 3 & Cash flows for investing activities & 0,160 \\
\hline 4 & Activity cash flow & $-0,271$ \\
\hline 5 & Gross profit & 0.229 \\
\hline 6 & EPS & 20,635 \\
\hline
\end{tabular}

Based on the table 4 above, multiple linear regression equations can be arranged:

$\mathrm{Y}=273,628-0,328 \mathrm{X}_{1}+0,160 \mathrm{X}_{2}+0,271 \mathrm{X}_{3}+0.229 \mathrm{X}_{4}+20,635 \mathrm{X}$

Shows the results of the constant value of stock value, if it has a variable component of cash flow, gross profit and earnings per share have significant results. However, only partially income per share has a significant value, because earnings per share is a source of return on shares.

TABLE V. F TEST RESULTS

\begin{tabular}{|c|l|c|}
\hline Test & F result & Sig \\
\hline Simultan & 98,120 & 0,000 \\
\hline
\end{tabular}

Based on the table 5, it is found that the $\mathrm{F}$ test value is 0.000 smaller 0.05 , so it can be stated that operating cash flow, investment cash flow, cash flow, gross profit and EPS together have a significant effect on stock returns.
TABLE VI. T TEST RESUltS

\begin{tabular}{|l|l|l|l|}
\hline No & \multicolumn{1}{|c|}{ Variable } & \multicolumn{1}{c|}{ t } & Sig \\
\hline 1 & Constant & $-1,006$ & 0.097 \\
\hline 2 & Cash flow from operating activities & 0.935 & 0.125 \\
\hline 3 & Cash flows for investing activities & -0.535 & 0.194 \\
\hline 4 & Activity cash flow & 0.824 & 0.152 \\
\hline 5 & EPS & 20.672 & 0.000 \\
\hline
\end{tabular}

Based on the table 6, it is found that the test results on the operating cash flow variable have a significance value of 0.097 , greater than 0.05 , so it can be judged that operating flow has no significant effect on stock returns. The investment cash flow variable has a significance value of 0.125 greater than 0.05 , so it can be stated that the investment cash flow has no significant effect on stock returns. Cash flow has a significance value of 0.194 greater than 0.05 , so it can be stated that cash flow has no significant effect on stock returns. Gross profit has a significance value of 0.152 greater than 0.05 , so it can be stated that gross profit has no significant effect on stock returns. EPS has a significance value of 0.000 less than 0.05 , so it can be stated that EPS has a significant effect on stock returns.

TABLE VII. DETERMINATION TEST

\begin{tabular}{|c|l|l|}
\hline R & R Square & Adjusted R Square \\
\hline 0,826 & 0,682 & 0,665 \\
\hline
\end{tabular}

The table 7 above shows the results of adjusting the R2 square of 0.682 . This means that $68.2 \%$ of the stock return variable will rely on the independent variables, namely operating flow, investment cash flow, cash flow, gross profit and EPS. In addition to the coefficient of determination, the coefficient is also obtained which shows the large value of the relationship between the independent variables, namely stock returns and operating flow, investment cash flow, cash inflow, gross profit and EPS, the value of $\mathrm{R}$ (version coefficient) is 0.826 , a value indicating that this relationship shows that the relationship between the independent variables operating cash flow, investment cash flow, cash flow, gross profit and EPS with the stock return variable is categorized as very strong because it is in the range of $0.6-0.8$.

Research that examines the effect of operating flow on stock returns which has no significant effect is the same as the research conducted by Takhtaei [13] because the highest and lowest values are between cash flow and stock returns in different companies. In terms of the effect of investment cash flow on stock returns, which has an insignificant effect in line with research conducted, Darmayanti [14] does not affect investment cash flow on the value of stock returns in manufacturing companies for the 2016-2018 period, an assessment of the average value of investment cash flows and stock returns that are not in sync. Where the value of investment cash flows tends to decrease, while the value of stock returns tends to increase every year. Testing the effect of the cash flow component has no significant effect in line with Pratama and Akbar [15], cash flow has a significant effect on stock returns, because the content of accounting information in the sample companies does not contain relevant information 
and market anomalies still occur due to failure of investors to understand accrual information. cash flow, market risk and conservatism. Research on the effect of gross profit on stock returns which has no significant effect is in line with Nurdiana [1], in the income statement, gross profit first, other income. The more detailed the calculation of profit figures, the more choice of accounting methods will be, so the quality will be lower. Research on the effect of gain per share on stock returns has a significant effect in line with Wicaksono [16] hypothesis and research on the ability of earnings per share to affect stock returns from the average value of earnings per share which tends to increase and is in line with the value of stock returns. The analysis shows that the components of cash flow and gross profit do not have a significant effect on stock returns, and earnings per share have a significant effect on stock returns. Many investors pay attention to Earning per share that can be obtained in the annual report because high earnings per share indicates the company is in good shape.

\section{CONCLUSION AND SUGGESTION}

Based on the results of research and discussion, it is found that cash flow has no significant effect on stock returns in manufacturing companies for the 2016-2018 period. Investment cash flow has no significant effect on stock returns in manufacturing companies for the 2016-2018 period. The flow of shares has no significant effect on stock returns in manufacturing companies for the 2016-2018 period. Gross profit has no significant effect on stock returns in manufacturing companies for the 2016-2018 period. Earning per share has a significant effect on stock returns in manufacturing companies for the 2016-2018 period. Operating cash flow, investment flow, cash flow, gross profit, and Earnings Per Share have a significant effect on stock returns in manufacturing companies for the 2016-2018 period. Suggestions for companies using earnings per share to determine investment and for companies that attract investors, you should pay attention to earnings per share contained in the financial statements so that investors are interested.

\section{REFERENCES}

[1] D. Nurdiana, "Pengaruh Informasi Laba, Arus Kas Dan Size Perusahaan Terhadap Return Saham Pada Perusahaan Food and Beverages Yang Terdaftar Di Bursa Efek Indonesia," Open J. Syst. STIE Galileo Batam, 2018.

[2] S. Apriyanti, "Pengaruh Komponen Arus Kas Terhadap Harga Saham Pada Perusahaan Manufaktur Sektor Industri Barang Konsumsi Yang Terdaftar Di Bursa Efek Indonesia,” J. ACSY Politek. Sekayu, 2017.

[3] N. Rizal and S.R. Ana, "Pengaruh Laba Akuntansi dan Arus Kas Serta Ukuran Perusahaan Terhadap Return Saham (Studi Empiris pada Perusahaan Perbankan yang terdaftar DI BEI Tahun 2012-2014),” J SPREAD, 2016.

[4] J. Hartono M, Teori portofolio dan analisis investasi (edisi Kesepuluh). 2015.

[5] P. Rahman, "Pengantar Akuntansi 1," Penerbit Erlangga, Jakarta, 2013.

[6] D. Martani, S. Veronica, R. Wardhani, A. Farahmita, and E. Tanujaya, "Akuntansi keuangan menengah berbasis PSAK," Jakarta: Salemba Empat, 2012.

[7] S.S. Harahap, "Analisis Krirtis Atas Laporan Keuangan," Jakarta: PT.Raja Grasindo Persada., 2011.

[8] Ikatan Akuntan Indonesia dalam PSAK No.2, "Laporan Arus Kas.," Lap. arus kas melaporkan arus kas selama periode tertentu dan diklasifikasikan menurut Akt. operasi, investasi, dan pendanaan, 2015.

[9] Hery, "Teori Akuntansi Pendekatan Konsep dan Analisis," Jakarta PT Grasindo, 2017.

[10] A. Hanafi, Mamduh M; Halim, “Analisis Laporan Keuangan, Edisi Keempat," Yogyakarta UPP STIM YKPN, 2012.

[11] A.H. Jusup, "Auditing (Pengauditan Berbasis ISA)," in Auditing (Pengauditan Berbasis ISA), 2014.

[12] V.W. Sujarweni, “Analisis Laporan Keuangan teori, aplikasi, dan hasi penelitian," in Analisis Laporan Keuangan teori, aplikasi, dan hasil penelitian, 2017.

[13] N. Takhtaei and H. Karimi, "Relative Ability of Earnings Data and Cash Flow in Predicting Future Cash Flows," Int. J. Account. Financ. Report., 2013, doi: 10.5296/ijafr.v3i1.3803.

[14] N. Darmayanti, "Pengaruh Laba Akuntansi, Komponen Arus Kas Dan Size Perusahaan Terhadap Return Saham (Study Kasus Perusahaan LQ45 Di Bei Tahun 2013-2017)," J-Macc, 2018.

[15] S. Pratama and D.A. Akbar, "Pengaruh laba akuntansi dan komponen arus kas terhadap return saham pada perusahaan manufaktur yang terdaftar di bursa efek indonesia," J. STIE MDP, 2012.

[16] B.W. Wicaksono, "Analisis Pengaruh Return On Asset, Earning Per Share, Dan Debt To Equity Ratio Terhadap Return Saham Pada Perusahaan Property Dan Real Estate Yang Terdaftar Di Bursa Efek Indonesia,” J. Manaj. Bisnis, 2019. 